\section{Isozymes for Cultivar Identification in Kiwifruit}

\author{
R. Messina, R. Testolin, and M. Morgante \\ Istituto di Produzione Vegetale, Universitá di Udine, I-33100 Udine, \\ Italy
}

Additional index words. Actinidia deliciosa, taxonomy, genetics, electrophoresis

Abstract. The usefulness of isozyme banding patterns as genetic markers in kiwifruit [Actinidia deliciosa (A. Chev.) C.F. Liang et A.R. Ferguson] was investigated using starch gel electrophoresis. Fifty-four entries putatively belonging to seven female and two male kiwifruit cultivars were examined for 13 enzyme systems (AAT, ACO, GDH, G6PDH, IDH, MDH, ME, MNR, NDH, 6PGD, PGI, PGM, and SKDH). Four enzyme systems, ACO, MDH, NDH, and SKDH, showed identical banding patterns in all clones surveyed. Of the remaining enzymes, AAT, PGI, and PGM had the best discriminating power. Six enzyme systems (GDH, G6PDH, IDH, ME, MNR, and 6PGD), though showing polymorphic banding patterns, were poorly resolved. All the New Zealand cultivars were uniquely identified by the simultaneous comparison of the AAT, PGI, and PGM zymograms. Some enzyme systems were also polymorphic among plants within the same cultivar, thus proving the heterogeneity of kiwifruit material introduced into Europe in the early 1970s.

Kiwifruit is a dioecious species with a high degree of ploidy, the somatic chromosome number being $2 \mathrm{n}=6 \mathrm{x}=170$ (Zhang and Beuzenberg, 1983) to 174 (McNeilage and Considine, 1989; Zhang, 1983). The chromosome counts are only approximate, because of the small and numerous chromosomes. The numbers reported for species with different degrees of ploidy suggest a ploidy series with $x=29$. Kiwifruit was domesticated in New Zealand at the beginning of this century. Plants from seeds brought back from China in 1904 by Isabel Frazer were planted on the Wanganui farm of Alexander Allison (Atkins, 1948 cited in Ferguson, 1983; Azam, 1983). Three seedlings from those open-pollinated vines gave rise through subsequent propagations by seed to all of the cultivars known today (Ferguson and Bollard, 1990; Ferguson and Lay Yee, 1983).

Morphological traits of nine distillate and three staminate clones of kiwifruit have been described (Zhang and Thorp, 1986) but the cultivars can be accurately identified only from the flowers or fruits. Vegetative features are quite similar and are strongly affected by environmental factors in all the clones (Zhang and Thorp, 1986).

The first commercial kiwifruit planting was established in Europe in the early 1970s, using plants from New Zealand (Ferguson and Bollard, 1990). In Italy, the first plants were imported from New Zealand and France (Testolin and Crivello, 1987). Some of those plants were unlabeled; others were incor-

Received for publication 15 May 1990. The research was supported by the National Research Council. Authors are grateful to A.R. Ferguson of D.S.I.R. Auckland, New Zealand, for supplying budwood collection. The cost of publishing this paper was defrayed in part by the payment of page charges. Under postal regulations, this paper therefore must be hereby marked advertisement solely to indicate this fact. rectly labelled; finally, other plants, although showing the traits of a given cultivar, did not fully match the standard cultivar deamong the tested kiwifruit entries. phenotype includes all the uncertain individuals. scription. The uncertainty in classifying such plants caused us to suspect that seedlings different from standard cultivars have been propagated and exported from New Zealand and/or France.

Identification of different clones of the same cultivar is the first step towards correct classification of kiwifruit germplasm. Moreover, identification of cultivars before the first flowering would be very useful for mass propagation. Such identification would become very important if mixups occur in manipulating plant stocks. Some authors have suggested distinguishing female from male vines by measuring peroxidase (Deng et al., 1982; Hirsch and Fortune, 1984, 1985) and dehydrogenase activities (Deng et al., 1982), but quantitative analysis often has poor discriminating power. Isozyme polymorphism has been successfully used to distinguish cultivars in various fruit trees (Arulsekar and Parfitt, 1986; Torres, 1983), but there have been few attempts to identify kiwifruit cultivars by means of enzyme analysis. Procedures for electrophoretic separation of isozymes in Actinidia spp. have been developed by Hirsch and Fortune (1984, 1985), Li et al. (1986), and Daoyu and Lawes (1987). Nevertheless, in all cases the band resolution was poor.

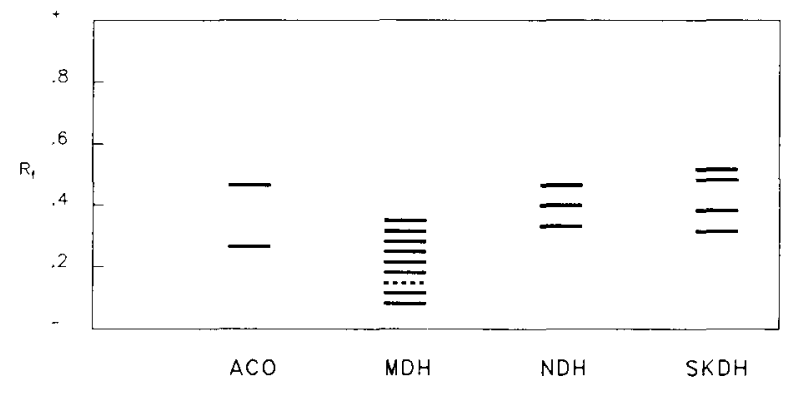

Fig. 1. Interpretative drawing of enzyme systems that did not show variation in banding patterns

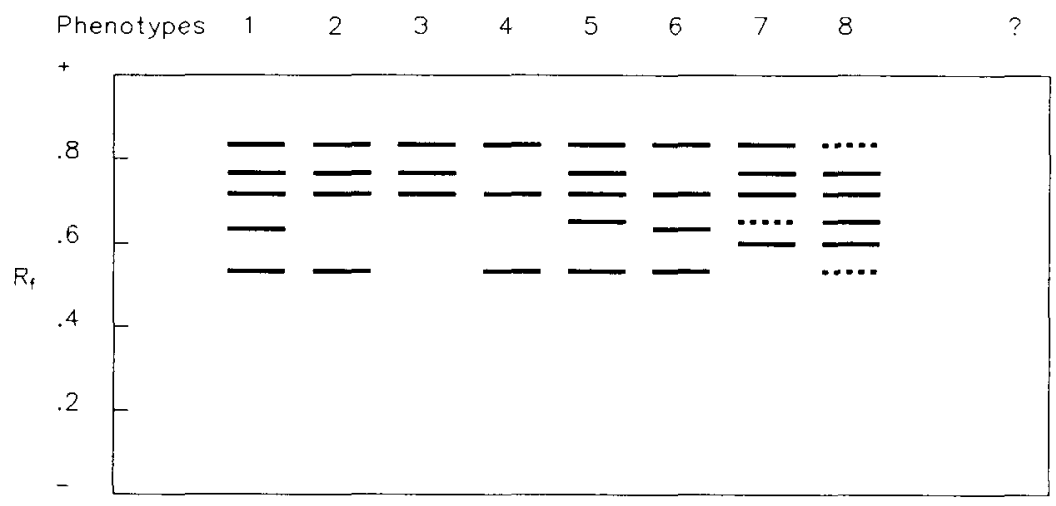

\begin{tabular}{|c|c|c|c|c|c|c|c|c|c|}
\hline Allison & $1^{*}$ & 1 & - & 2 & - & - & - & - & 2 \\
\hline Bruno & 1 & - & - & $2^{*}$ & - & - & - & - & 4 \\
\hline Constricted & - & - & $1^{*}$ & - & - & - & - & - & - \\
\hline Elmwood & - & - & - & - & - & - & - & - & $2^{*}$ \\
\hline Gracie & 2 & - & - & - & - & $1^{*}$ & - & - & 1 \\
\hline Hayward & - & - & - & - & $23^{*}$ & - & - & - & 1 \\
\hline Monty & - & - & - & $5 *$ & - & - & - & - & - \\
\hline Matua & $1^{*}$ & - & - & - & - & - & 2 & - & - \\
\hline Tomuri & - & - & - & - & - & - & - & $2^{*}$ & - \\
\hline
\end{tabular}

Fig. 2. Interpretative drawing of AAT banding patterns and their frequency within the tested kiwifruit cultivars. The numbers with an asterisk (*) include the New Zealand standard clones. The ?-named 


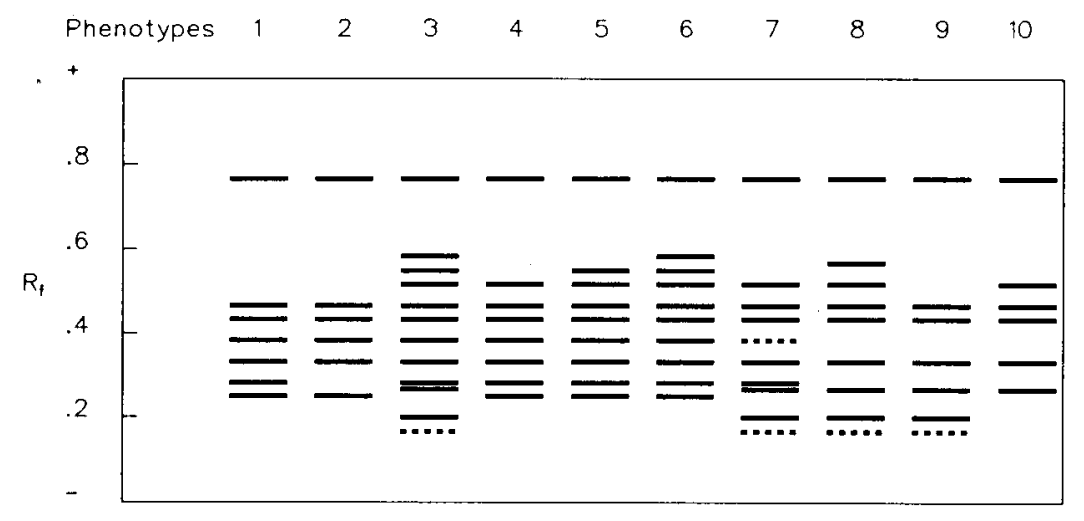

\begin{tabular}{|c|c|c|c|c|c|c|c|c|c|c|}
\hline Allison & $1^{*}$ & 1 & 2 & 2 & - & - & - & - & - & - \\
\hline Bruno & 1 & - & - & 1 & $3 *$ & 2 & - & - & - & - \\
\hline Constricted & - & - & - & $1^{*}$ & - & - & - & - & - & - \\
\hline Elmwood & - & - & - & - & - & $1^{*}$ & 1 & - & - & - \\
\hline Gracie & - & $2^{*}$ & - & - & - & 2 & - & - & - & - \\
\hline Hayward & - & - & - & - & - & - & $23^{*}$ & - & - & 1 \\
\hline Monty & - & - & - & $5 *$ & - & - & - & - & - & - \\
\hline Matua & - & - & - & - & - & $1^{*}$ & - & 2 & - & - \\
\hline Tomuri & - & - & - & - & - & - & - & - & $2^{*}$ & - \\
\hline
\end{tabular}

Fig. 3. Interpretative drawing of PGI banding patterns and their frequency within the tested kiwifruit cultivars. The numbers with an asterisk $(*)$ include the New Zealand standard clones.

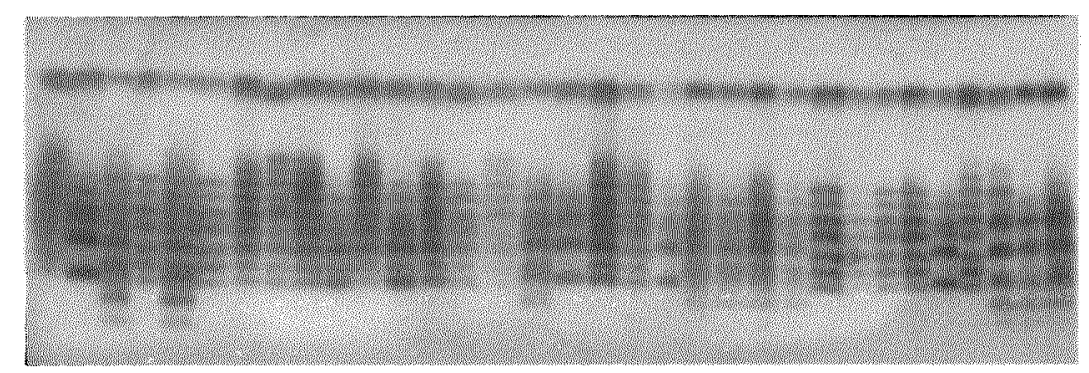

Fig. 4. PGI starch gel showing often different banding patterns in individuals putatively belonging to the same cultivar. From left 'Allison' (lanes 1-5), 'Bruno' (lanes 6-12), 'Constricted' (lane 13), 'Elmwood' (lanes 14, 15), 'Gracie' (lanes 16-19), 'Hayward' (lanes 20-23), 'Monty' (lanes 24-27), 'Matua' (lanes 29, 30), 'Tomuri' (lanes 31, 32).' In lane 28 there is an unclassified vine.

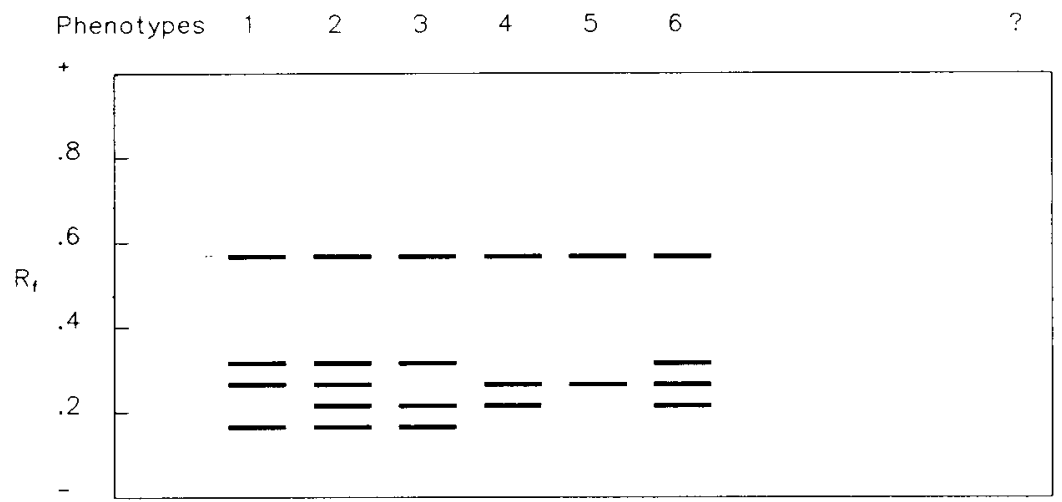

$\begin{array}{lccccccc}\text { Allison } & 1^{*} & 1 & 2 & 2 & - & - & - \\ \text { Bruno } & - & - & - & - & 2^{*} & 4 & 1 \\ \text { Constricted } & - & - & - & - & - & 1^{*} & - \\ \text { Elmwood } & - & 1 & - & - & - & 1^{*} & - \\ \text { Gracie } & - & - & 2^{*} & 1 & - & - & - \\ \text { Hayward } & - & 24^{*} & - & - & - & - & - \\ \text { Monty } & - & - & - & 5^{*} & - & - & - \\ \text { Matua } & - & 2 & - & - & - & 1^{*} & - \\ \text { Tomuri } & 2^{*} & - & - & - & - & - & -\end{array}$

Fig. 5. Interpretative drawing of PGM banding patterns and their frequency within the tested kiwifruit cultivars. The numbers with an asterisk $(*)$ include the New Zealand standard clones. The ?-named phenotype includes all the uncertain individuals.
The present research was carried out to characterize kiwifruit cultivars, particularly the female 'Hayward' and the males 'Matua' and 'Tomuri', which are the most widely grown throughout the world, and to investigate the variability of germplasm introduced from New Zealand and France to Italy in the early 1970 s.

Fifty-four kiwifruit entries provisionally ascribed to seven female cultivars (Allison, Bruno, Constricted, Elmwood, Gracie, Hayward, and Monty) and two male cultivars (Matua and Tomuri) were examined for 13 enzyme systems (Table 1). Plant material came from a germplasm collection maintained at the Univ. of Udine. Reference vines of each cultivar were supplied by A.R. Ferguson (New Zealand),

Apices from swelling buds were removed from single node canes forced to break dormancy in jars of water at room temperature. Other materials, including shoot tips, and young and old leaves from field-grown plants were also tested. Samples of $\approx 0.02 \mathrm{~g}$ of fresh material were crushed in $50 \mu \mathrm{l}$ of $0.1 \mathrm{M}$ Tris $\cdot \mathrm{HCl}$ pH 7.3 extraction buffer to which 5\% PVPP, $1 \%$ mercaptoethanol, $0.12 \%$ EDTA, and $0.1 \%$ dithiothreitol had been added (G. Müller-Starck, personal communication). Extracts were absorbed onto Whatman 3MM chromatography paper wicks and used immediately for electrophoretic analysis. All steps in the extraction procedures were performed in an ice bath.

Electrophoresis was carried out on $11 \%$ w/v horizontal starch gel at 4C using 30 $\mathrm{V} / \mathrm{cm}$ for buffer systems $\mathrm{A}$ and $\mathrm{B}, 6 \mathrm{~mA} / \mathrm{cm}$ for buffer systems $\mathrm{F}$ and $\mathrm{G}$, and $12 \mathrm{~mA} / \mathrm{cm}$ for the remaining buffer systems (Table 2). After $5 \mathrm{~h}$, gels were cut horizontally to yield 1.5-mm-thick slices. Enzyme staining procedures were taken from Cheliak and Pitel (1984), with the following modification: in AAT staining, $0.2 \%$ EDTA and $0.01 \%$ arsenate were added (Harris and Hopkinson, 1976). Analysis of banding patterns of each enzyme system was carried out on at least three gels run under the same conditions. The most difficult-to-read gels were repeated many more times.

Of the 13 enzyme systems investigated, four did not show variability (Fig. 1), and so are not useful for cultivar classification. These are ACO, MDH, NDH, and SKDH. Six enzyme systems, G6PDH, GDH, IDH, ME, MNR, and 6-PGD, gave poor band resolution and/or light staining for all the electrophoretic buffer systems tested (Table 2); thus, neither photographs nor interpretative drawings are reported. ATT, PGI, and PGM, showed considerable variation among cultivars.

In AAT two zones of activity occur. In the lower zone, up to seven slowly migrating bands can be identified. They are distributed almost regularly between $\mathrm{R}_{\mathrm{f}} 0.09$ and 0.41 . As bands at both the extremities were always faint and not consistently storable, that zone is not further discussed. The anodal zone ranges from $R_{f} 0.57$ to 0.82 and shows six bands, three of which are not easy to score 
Table 1. Electrophoretic (EF) buffer systems tested for 13 enzyme systems in kiwifruit.

\begin{tabular}{|c|c|c|c|}
\hline \multirow{2}{*}{ Acronym } & \multirow[b]{2}{*}{ Enzyme system (EC number) } & \multicolumn{2}{|c|}{ EF buffer systems ${ }^{z}$} \\
\hline & & Best resolution & Others \\
\hline AAT & Aspartate amino transferase $(2.6 .1 .1)$ & B & A \\
\hline $\mathrm{ACO}$ & Aconitase $(4.2 .1 .3)$ & B & C E G \\
\hline GDH & Glutamate dehydrogenase $(1.4 .1 .2)$ & -.- & A B C D \\
\hline G6PDH & Glucose-6-phosphate dehydrogenase (1.1.1.49) & -.- & A C D E I \\
\hline IDH & Isocitrate dehydrogenase (1.1.1.42) & --- & C E F G I \\
\hline MDH & Malate dehydrogenase $(1.1 .1 .37)$ & $\mathbf{F}$ & C E G H \\
\hline ME & Malic enzyme $(1 \cdot 1.1 .40)$ & ... & C E F G \\
\hline MNR & Menadione reductase $(1.6 .99 .2)$ & -.. & B C E \\
\hline NDH & NADH dehydrogenase (1.6.99.3) & $\mathrm{C}$ & B \\
\hline 6PGD & 6-Phosphogluconate dehydrogenase (1.1.1.44) & -.- & C E F G H \\
\hline PGI & Phosphoglucose isomerase $(5.3 .1 .9)$ & B & A C D F G H I \\
\hline PGM & Phosphoglucomutase (2.7.5.1) & $\mathrm{E}$ & B C F G \\
\hline SKDH & Shikimate dehydrogenase (1.1.1.25) & $\mathbf{F}$ & $\mathrm{C} \mathrm{G}$ \\
\hline
\end{tabular}

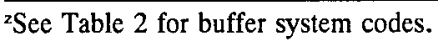

Table 2. Electrophoretic buffer systems used for analysis of kiwifruit.

\begin{tabular}{|c|c|c|c|}
\hline $\begin{array}{l}\text { Buffer } \\
\text { system }\end{array}$ & Composition & $\mathrm{pH}$ & Reference \\
\hline A & $\begin{array}{l}\text { Tray } 0.04 \mathrm{M} \mathrm{LiOH}, 0.19 \mathrm{M} \text { boric acid } \\
\text { Gel } 0.05 \mathrm{M} \text { Tris, } 7 \mathrm{~mm} \text { citric acid } \\
\text { Add } 1: 9 \text { tray buffer }\end{array}$ & 8.3 & $\begin{array}{l}\text { Modified from Ashton and } \\
\text { Braden (1961) cited in Conkle } \\
\text { et al. (1982) }\end{array}$ \\
\hline B & $\begin{array}{l}\text { Tray } 0.3 \mathrm{M} \text { boric acid, } 0.06 \mathrm{M} \mathrm{NaOH} \\
\text { Gel } 0.08 \mathrm{M} \text { Tris, } 7 \mathrm{mM} \text { citric acid }\end{array}$ & $\begin{array}{l}8.2 \\
8.7\end{array}$ & Modified from Poulik (1957) \\
\hline $\mathrm{C}$ & $\begin{array}{l}\text { Tray } 0.13 \mathrm{M} \text { Tris, } 46 \mathrm{~mm} \text { citric acid } \\
\text { Gel } 1: 4 \text { diluted tray buffer }\end{array}$ & 7.0 & $\begin{array}{l}\text { Modified from Shaw and } \\
\text { Prasad (1970) }\end{array}$ \\
\hline D & $\begin{array}{l}\text { Tray } 0.11 \mathrm{M} \text { Tris, } 2.5 \mathrm{~mm} \text { EDTA, } 0.06 \mathrm{M} \\
\text { boric acid } \\
\text { Gel } 1: 10 \text { diluted tray buffer }\end{array}$ & 8.6 & Harris and Hopkinson (1976) \\
\hline E & $\begin{array}{l}\text { Tray } 0.047 \mathrm{M} \text { citric acid adjusted to } \\
\mathrm{pH} \text { with } \mathrm{NaOH} \\
\text { Gel } 5 \mathrm{~mm} \text { Histidine (hydrochloride mono- } \\
\text { hydrate) adjusted to pH with } \mathrm{NaOH}\end{array}$ & 7.0 & $\begin{array}{l}\text { S.D. Tanksley (pers. comm.) } \\
\text { cited in Shields et al. } \\
\text { (1983) as system E }\end{array}$ \\
\hline $\mathrm{F}$ & $\begin{array}{l}\text { Tray } 0.065 \mathrm{M} \mathrm{L} \text {-Histidine (free base), } \\
0.02 \mathrm{M} \text { citric acid } \\
\text { Gel } 1: 6 \text { diluted tray buffer }\end{array}$ & 5.7 & $\begin{array}{l}\text { Brown et al. (1978) cited in } \\
\text { Wendel and Stuber (1984) }\end{array}$ \\
\hline G & $\begin{array}{l}\text { Tray } 0.04 \mathrm{M} \text { citric acid adjusted to } \mathrm{pH} \\
\text { with } \mathrm{N} \text {-(3-aminopropyl) morpholine } \\
\text { Gel } 1: 19 \text { diluted tray buffer }\end{array}$ & 6.1 & $\begin{array}{l}\text { Clayton and Tretiak (1972) } \\
\text { cited in Conkle et al. (1982) }\end{array}$ \\
\hline $\mathrm{H}$ & $\begin{array}{l}\text { Tray } 0.245 \mathrm{M} \mathrm{NaH}_{2} \mathrm{PO}_{4}, 0.15 \mathrm{M} \text { citric } \\
\text { acid } \\
\text { Gel } 1: 40 \text { diluted tray buffer }\end{array}$ & 5.9 & Harris and Hopkinson (1976) \\
\hline I & $\begin{array}{l}\text { Tray } 5.8 \mathrm{mM} \mathrm{Na}_{2} \mathrm{HPO}_{4}, 4.2 \mathrm{mM} \mathrm{NaH}_{2} \mathrm{PO}_{4}^{\mathrm{z}} \\
\text { Gel 1:10 diluted tray buffer }\end{array}$ & 7.0 & $\begin{array}{l}\text { Modified from Richardson et } \\
\text { al. (1986) }\end{array}$ \\
\hline
\end{tabular}

${ }^{2}$ Add $10 \mathrm{mg}$ NADP to $500 \mathrm{ml}$ cathodal buffer and $4 \mathrm{mg}$ NADP to $200 \mathrm{ml}$ gel.

Table 3. Classification of New Zealand standard kiwifruit cultivars according to their AAT, PGI, and PGM phenotypes.

\begin{tabular}{lccc}
\hline \hline & \multicolumn{3}{c}{ Phenotypes $^{2}$} \\
\cline { 2 - 4 } Cultivar & AAT & PGI & PGM \\
\hline Female & & & \\
Allison & 1 & 1 & 1 \\
Bruno & 4 & 5 & 5 \\
Constricted & 3 & 4 & 6 \\
Elmwood & $?$ & 6 & 6 \\
Gracie & 6 & 2 & 3 \\
Hayward & 5 & 7 & 2 \\
Monty & 4 & 4 & 4 \\
Male & & & \\
Matua & 1 & 6 & 6 \\
Tomuri & 8 & 9 & 2 \\
\hline
\end{tabular}

'See Figs. 2-4 for phenotype banding patterns.

(Fig. 2). The band at $\mathrm{R}_{\mathrm{f}}, 0.57$ occurs in all female strains, except the single 'Constricted' vine, it occurs also in New Zealand standard 'Matua', but not in the two entries collected in Italian orchards and classified as 'Matua'. In both 'Tomuri' accessions the band
In PGI, two zones of activity can be distinguished. The fastest migrating one is monomorphic and shows a single band at $R_{f}$ 0.76 from the origin (Fig. 3). The other is polymorphic and shows 10 phenotypes, The accessions can be distinguished through the presence or absence of the two more cathodal bands $\left(\mathrm{R}_{\mathrm{f}} 0.15\right.$ and 0.20$)$; the polymorphism of the region just above the two cathodal bands; the presence or absence of a band at $R_{f} 0.38$, and the presence of a different number of bands between $R_{f} 0.51$ and 0.58 .

'Allison' and 'Bruno' proved once again to be very heterogeneous, each one showing four different phenotypes (Fig. 4). Individuals from 'Elmwood', 'Gracie', 'Hayward', and 'Matua' germplasm also showed different phenotypes within the same cultivar, whereas the female 'Monty' and the male 'Tomuri' showed a single phenotype as for AAT.

In PGM, two zones of activity can be distinguished. The most anodal zone, which stained at $R_{f} 0.54$, was monomorphic in all individuals. In the second zone, one to four bands of activity were detected (Fig. 5). Six phenotypes could be distinguished using these cathodal bands.

'Allison', as in AAT and PGI, showed the largest number (four) of phenotypes. Two patterns have been found in 'Bruno', 'Elmwood', 'Gracie', and 'Matua', respectively. Both 'Monty' and 'Tomuri' showed a single banding pattern. 'Hayward' showed a single pattern if only the number of bands is taken into consideration. Nevertheless, it should be easy to distinguish different staining intensities in phenotypes showing the same banding pattern. This is, for example, the case of the 24th 'Hayward' individual, which had a four-banded, uniformly staining pattern at the cathodal region, in contrast to the remaining individuals, in which the third band from the cathode was more heavily stained than the others.

An analysis of the morphological traits of fruits suggested that most of the kiwifruit cultivars present in Europe are composed of different clones (Testolin and Crivello, 1987). Isozyme analysis confirmed this supposition. As the multilocus isozyme genotypes of most of the apparently misidentified clones do not match those of any of the reference vines, the most likely hypothesis is that some seedlings were propagated together with standard cultivars in the early 1970s, when the demand for kiwifruit plants was high in Europe and in New Zealand. For a minority of clones, on the contrary, mislabeling could have occurred. Since 'Hayward' is the almost exclusively grown female cultivar and since it is nearly uniform, selection is urgently needed only among the 'Matua' types.

The New Zealand standard cultivars are easily separated through the analysis of AAT, PGI, and PGM zymograms (Table 3). The strong differences in staining intensity of the same band, which may give an additional tool for distinguishing among phenotypes, could be caused by variation in allele dosage as a consequence of the high ploidy level of 
kiwifruit. Nevertheless, other causes, such as variation in gene expression, post transcriptional or post translational effects, cannot be excluded.

Shoot tips collected at bud swell were the most suitable material. Young and fully expanded leaves showed, for most enzyme systems, lower activity and/or poor band resolution. All attempts to separate and stain some enzyme systems, such as AAT, in kiwifruit leaf extracts failed, although most of the usual and sometimes unusual laboratory techniques for extraction and gel running were tested. We do not know the reason for this failure. Enzymes possibly are inactivated or destroyed during leaf extract preparation or electrophoresis by the actinidin, a thiol protease. The addition of PMSF (phenylmethylsulphonyl fluoride) to the extraction buffer did not improve AAT resolution (unpublished data).

\section{Literature Cited}

Arulsekar, S. and D.E. Parfitt. 1986. Isozyme analysis procedures for stone fruits, almond, grape, walnut, pistachio and fig. HortScience 21:928-933.

Azam, B. 1983. L'histoire de l'Actinidia chinensis. Purpan 126:7-13.

Cheliak, W.M. and J.A. Pitel 1984. Techniques for starch gel electrophoresis of enzymes from forest tree species. Petawawa National Forestry Institute-Can. For. Serv., Info. Rpt. PI-X-42.

Conkle, M.T., P.D. Hodgskiss, L.B. Nunnally, and S.C. Hunter. 1982. Starch gel electrophoresis of conifer seeds: a laboratory manual. U.S. Dept. Agr. Forest Service, Pacific Southwest Forest and Range Expt. Sta. Gen. Tech. Rpt. PSW-64

Deng, Y., X. Shangguan, Z. Zhou, and J. Cao. 1982. A preliminary report of studies on identification "of the female and male vine of Actinidia chinensis Planch. Acta Hort. Sinica 9:6366.

Ferguson, A.R. 1983. E.H. Wilson, Yichang, and the kiwifruit. Arnoldia 43:24-35.

Ferguson, A.R. and E.G. Bollard. 1990. Domestication of the kiwifruit, p. 165-246. In: I.J. Warrington and G.C. Weston (eds.). Kiwifruit science and management. Ray Richards Publisher, Auckland, New Zealand.

Ferguson, A.R. and M. Lay Yee. 1983. Kiwifruit, p. 111-116. In: G.S. Wratt and H.C. Smith (eds.). Plant breeding in New Zealand. Butterworths of New Zealand, Wellington, New Zealand.

Harris, H. and D.A. Hopkinson. 1976. Handbook of enzyme electrophoresis in human genetics. North-Holland Publishing Co., Amsterdam.

Hirsch, A.M. and D. Fortune. 1984. Peroxidase activity and isoperoxidase composition in cultured stem tissue, callus and cell suspensions of Actinidia chinensis. Z. Pflanzenphysiol. 113:129-139.

Hirsch, A. M., and D. Fortune. 1985. Peroxidase as markers of organogenesis and dioecism in tissue of Actinidia chinensis L. Planchon cultured in vitro, p. 361-365. In: H. Greppin, C. Penel, and T. Gaspar (eds.). Molecular and physiological aspects of plant peroxidase. Univ. of Geneve.

Li, C.Z., H.Y. Hua, and M.Z. Xu. 1986. A study on the application of isoenzyme analysis to the identification of sex in Actinidia chinensis. Plant Physiol. Commun. 2:12-13.

McNeilage, M.A. and J.A. Considine. 1989 Chromosome studies in some Actinidia taxa and implications for breeding. New Zealand J. Bot. 27:71-81.

Poulik, M.P. 1957. Starch gel electrophoresis in a discontinuous system of buffers. Nature (London) 180:1477-1479.

Richardson, B.J., P.R. Baverstock, and M. Adams. 1986. Allozyme electrophoresis. A handbook for animal systematic and population studies. Academic, Sydney.

Shaw, C.R. and R. Prasad. 1970. Starch gel electrophoresis. A compilation of recipes. Biochem. Genet. 4:297-320

Shields, C.R., T.J. Orton, and C.W. Stuber. 1983. An outline of general resource needs and procedures for the electrophoretic separation of active enzymes from plant tissues, p. 443-468. In: S.D. Tanksley and T.J. Orton (eds.). Isozymes in plant genetics and breeding, Part A. Elsevier, Amsterdam.

Testolin, R. and V. Crivello. 1987. Il kiwi e il suo mondo (Kiwifruit and its world). IRIPAQuadrifoglio, Mestre-VE, Italy.

Torres, A.M. 1983. Fruit trees, p. 401-421. In S.D. Tanksley and T.J. Orton (eds.). Isozymes in plant genetics and breeding, Part B. Elsevier, Amsterdam.

Wendel, G.F. and C.W. Stuber. 1984. Plant isozymes: enzymes studied and buffer systems for their electrophoretic resolution in starch gels. U.S. Dept. Agr.-Agr. Res. Serv. and Dept. of Genetics, North Carolina State Univ., Raleigh. Isozyme Bul. 17:4-11.

Zhang, Z.-Y. 1983. A report on the chromosome numbers of two varieties of Actinidia chinensis Planch. Acta Phytotax. Sinica 21:161-163.

Zhang, J. and E.J. Beuzenberg. 1983. Chromosome numbers in two varieties of Actinidia chinensis Planch. New Zealand J. Bot. 21:353355.

Zhang, J. and T.G. Thorp. 1986. Morphology of nine distillate and three staminate New Zealand clones of kiwifruit (Actinidia deliciosa (A. Chev.) C.F. Liang et A.R. Ferguson var. deliciosa). New Zealand J. Bot. 24:589-613.

Zhu, D.-Y. and G.S. Lawes. 1987. Characterization of kiwifruit (Actinidia deliciosa) cultivars by gel electrophoresis. Acta Hort. 282:395398. 